\title{
¿Is Democracy in Latin America not liberal and is liberalism not democratic?
}

\section{¿La democracia en América Latina no es liberal y el liberalismo no es democrático?}

Andrés Gómez Polanco

Recepción: 27-04-2020

Aceptación: 13-07-2020

\begin{abstract}
Latin American democracy has been a controversial concept due to its different interpretations by scholars and political actors. Some authors emphasize its illiberal character and other ones its elitist notion. This essay will argue that democracy, in the region, has been a symbiosis between non-democratic liberalism and illiberal democracy. Therefore, the feasibility of this democracy with adjectives has been channelized by populist phenomenon.
\end{abstract}

Key words: Illiberal democracy, non-democratic liberalism, populism, institutions, inclusion.

\section{Resumen}

La democracia en América Latina ha sido un concepto controversial debido a las diferentes interpretaciones realizadas por académicos y actores políticos. Algunos autores enfatizan su carácter iliberal y otros su carácter elitista. Este ensayo académico establece que la democracia latinoamericana ha sido una simbiosis entre un liberalismo antidemocrático y una democracia iliberal. Por lo tanto, la viabilidad de esta democracia con adjetivos ha sido canalizada a través de los fenómenos populistas.

Palabras claves: Democracia iliberal, liberalismo antidemocrático, populismo, instituciones, inclusión. 


\section{Introduction}

$\mathrm{D}$ emocracy in Latin America has been a permanent issue of academic debates in recent decades, such as transition from authoritarian government to a democratic regime, quality of democracy, institutional arrangements, accountability and rule of law, or the relationship between populism and democracy. As can be seen, democracy is a multidimensional political subject that is constantly being interpreted and analysed in the region.

Generally, the academic mainstream points out the analysis of democracy as a dichotomy between pure democratic regimes and different forms of authoritarianism. The latter is a respectable position, but debatable because in the political reality there has been different kind of regimes which combine a range of liberal and illiberal characteristics. Thus, arguing that democracy is essentially liberal and any illiberal regime is not democratic could represent academic purism. However, this kind of analysis cannot be an appropriate framework to understand the complexity of political regimes, especially in Latin America.

Furthermore, in order to de-articulate this antagonistic vision between 'good democratic regimes' (the pure ones) and all the rest authoritarian ones, democracy must be understood in a gradual and integral form. The representative of this analytical framework is Robert Dahl. He conceives that democracy "is fundamentally characterized by its continuous ability to respond to the preferences of its citizens, without establishing political differences between them" (2002, pp. 13). Therefore, as far as Dahl is concerned, democracy is a political regime which establishes limits and red lines that differentiate this institutional arrangement and its different approaches than undemocratic regimes.

In this vein, a political regime in order to be considered democratic must respect and guarantee the preferences of its citizens without political exclusions. This institutional arrangement is based on the liberty and the validity of equal opportunities in areas such as: (1) formulating of preferences, (2) Expressing publicly these preferences among their supporters, opposition 
and, the government; and (3) having equal treatment from the government. (Dahl, 2002, pp. 14). These minimum conditions pave the way for the construction and consolidation of democracy through social, political and legal institutions. The latter represents the democratic rules and arrangements which guarantees the democratic rule in the dispute of power. This notion of democracy depends on the institutionalization of norms and values rather than government effectiveness. Hence, Dahl points out the materialization of these principles and rules; for instance: “(1) Freedom of association, (2) Freedom of expression, (3) Freedom of vote, (4) Political Competition, (5) Diversity of sources of information, (6) Free and fair elections, (7) Eligibility for the public sector, and (8) Institutions that guarantee that policies depend on votes and other ways of expressing preferences" (Dahl, 2002, pp. 15).

Thus, the three basic democratic conditions and the eight institutions allow the configuration of a democratic political regime based on minimums. However, it is an ideal and theoretical concept to analyze and study democracy, not a pure and unquestionable reality. Dahl was aware regarding the feasibility of his academic work before the complex and multidimensional political reality. In that sense, his democratic theory recognizes the variation of the conditions and institutions which make possible a democratic regime.

As a result, Dahl developed two theoretical elements in order to adapt his notion of democracy to the political reality. These elements are: participation (capacity for representation) and public debate (capacity for opposition). The former "is the number of people empowered to participate, on a level of greater or lesser equality, in the control and discussion of government policy" (Dahl, 2002, pp. 15). In other words, it refers the inclusion of citizens thorough representatives in the political system, preferably through formal mechanisms such as voting (popularization).

Since the right to vote and representation are necessary, but not sufficient elements to consolidate a minimum democracy. The guarantees and respect of opposition is the second element (liberalization) to adapt Dahls' democratic theory to the real world. Besides, "when the right to oppose is not guaranteed, a significant part of the population is stripped of the right to participate on the public debate" (Dahl, 2002, pp. 16). 
Therefore, pure democracy is a theoretical ideal which is based on liberal rights and institutional arrangements. However, democratic regimes are generally dynamic and hybrid. These institutions and rights (popularization and liberalization) are rarely represented in their pure versions. Therefore, according to Dahl, in the socio-political reality there are no perfect or absolute democracies, but there are polyarchies which are "relatively (but not completely) democratic regimes; or, substantially liberalized and popularized systems, that is, very representative and open to public debate" (2002, pp. 18).

The Dahlian democracy or polyarchies are the core analytical explanation regarding the validity of understanding and analyzing democracy as a multiple combination of ideas, ideologies, and actions. In this framework the question that is going to guide this essay is the following: Is Democracy in Latin America not liberal and is liberalism not democratic? The latter research question argues the academic mainstream regarding pure democracy because its motivation is to demonstrate that liberalism and democracy are not necessarily inseparable elements of a single concept.

In that sense, the author's hypothesis is that in Latin America illiberal democracy and non-democratic liberalism have been the forms of hybrid democracies in the last decades, and populism has been their causal mechanism. This essay will be organized in the following manner. Firstly, a theoretical discussion will be developed which will explain why liberalism is not democratic in Latin America. Secondly, populism will be positioned as an intervening factor between constitutional democracies and illiberal democracies. Thirdly, there will be a theoretical discussion about the preeminence of the illiberal democracies in the region.

\section{Why is liberalism nondemocratic in Latin America?}

Liberalism is a philosophical, economic, cultural and political paradigm that has shaped Western civilization. As a result of the process of colonization, Latin America embraced its values and principles. As far as this essay is concerned, liberalism is understood in its integrity as a political and economic ideology which emphasizes individual liberties over any form of 
state's control (Wiarda and Skelley 2005, p. 166). Although both political and economic notions of liberalism are essentially based on freedom, it is important to clarify that the former express liberal values regarding citizen participation in public issues. And the latter reflects the market-oriented economy rather than state-oriented one (laissez-faire/laissez-passer). Both, the economic and political notions of liberalism could be materialized in one single regime such as the cases of Reagan's and Thatcher's governments. However, there are also cases that combine just one liberal notion; for instance, Chinese Communist Party, after Mao's death, has a kind of liberal economy in the framework of a totalitarian regime. Another example is the case of Social Democratic organizations which are in favour of political liberalism, but they prefer state-oriented economic policies.

Furthermore, in the following years after the collapse of the Soviet Union, 1991, a new understanding of liberalism emerged, regardless its academic accuracy, which was called neoliberalism. Francis Fukuyama observes neoliberalism as "the end of the history ... only democracy and market capitalism were triumphant, without competition, in the basis of the competition of ideas and great systems' (2006, p. 45). Thus, (neo) liberalism was conceived as one single ideology, its economic and political notions were integrated in one single ideology that was the expression of the victory of free market economies and constitutional democracies. The latter is not a misunderstanding of the difference in academic terms between political liberalism and economic one, it is the materialization of the Latin American political reality in the late years of the XX century. For instance, the elected presidents Febres Cordero in Ecuador, Belaunde Terry in Peru, Alfonsin in Argentina, and so on are examples of this combination in the practice.

In the last decades, the majority of Latin American countries experienced economic and political processes which had crucial consequences in their socio-political regimes. The latter was the third wave of democratization and the former was the free market adjustments. Both of them influenced the understanding and practices of Latin American democracy since the new regime was built on the basis of political liberties against dictatorships and economic reforms in favour of capitalism. 
The new democracy was a democracy with an adjective, liberal or constitutional, which means that this regime embodied the main political values of liberalism such as free and fair elections, separation of powers, rule of law, institutionalized powers, checks and balances, independent judiciary, transparency and accountability, citizenship's participation (beyond votes), and basic liberties of speech, association, press, public opinion, assembly, religion and property (Kruijt 2001, p. 421; Close and Deonadan 2004, p. 3; Zakaria 1997, p. 25). Consequently, Latin American democracies were built or were tried to build in the basis of constitutional liberalism which emphasizes individual rights, equality under the law, and controlling the power throughout institutions.

This conception of liberalism is focused mainly on constitutional and formal elements such as procedures, mechanisms, institutions, and law; but it does not mean that constitutional liberalism necessarily embodies democracy. As Gonzalo Bustamante points out 'liberal democracy is based on legal procedures, bureaucratic administration, and institutions which depoliticize the collective political action' (2010, p. 20). Hence, the first factor to say that liberalism is not democratic in Latin America is the protagonist role of the traditional political parties, political class, bureaucratic apparatus, and representatives (formal institutions) as the owners of democracy instead of citizens' participation. In summary, liberalism reduces the effectiveness of the collective political action, democracy, throughout depoliticizing processes and mechanisms.

For instance, Latinobarometro's report from 1995 to 2015 demonstrates that the support for democracy as an institutional arrangement rose slightly from $68 \%$ in 2002 to $72 \%$ in 2015 . This data could be argued to be a proof of the legitimization and consolidation of the liberal democracy in the region. However, the graph shows that this increase occurred in the late years of the XX century which was the period of emergence of illiberal and authoritarian Latin American Leaders such as: Chavez' Venezuela in 1998, Kirchner's Argentina in 2003, Morale's Bolivia in 2005, and Correa's Ecuador in 2006. 


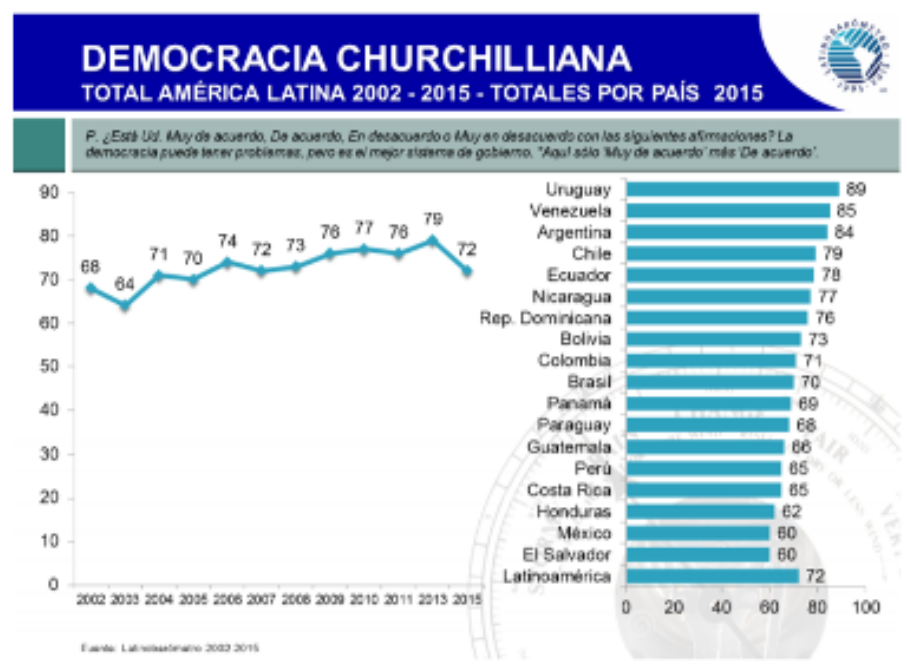

In other words, if this indicator measures the support of democracy as an institution rather than democracy for its results, the influence of populism to legitimize this political regime is crucial. The latter is based on that 4 out of 6 countries that occupied the first positions in the graph are Venezuela with $85 \%$, Argentina $84 \%$, Ecuador $78 \%$, and Nicaragua with $77 \%$ (Latinobarometro 2015). Hence, this hypothesis of the article considers populism as the causal mechanism from non-democratic liberalism to illiberal democracy thorough plebiscitarian and non-institutional participation of the 'people' rather than the liberal procedures and mechanisms.

Furthermore, elites have historically dominated Latin American political parties and political systems. Since the third wave of democratization (1980s) these elites were represented in political parties which monopolized political participation through closed political systems in order to consolidate political and governmental institutionalization (liberal/constitutional democracy). As a result, traditional political parties incarnated democracy, and the latter was reduced as a mere peaceful process of elites' fighting for power. As Schumpeter says 'democracy is the mechanism of competition between leaders, such a market structure. Although there are periodical elections in 
order to legitimize governments, the policy programs are seen as the result of institutions' negotiations rather than people's will' (1994, p. 315).

In this context, the well-known Dahlian democracy (Polyarchic), which emphasizes civic and political rights as the principal factors to constitute a democratic regime (Dahl 2002, p. 14), forgets that pluralism, liberties and participation could be kidnapped for different actors, even the liberal ones. For instance, Latin American party systems from 1980s to 2000s such as Ecuador (ID, PRE, PSC, CFP, MPD, DP, etc.) and Peru (PPC, APRA, AP, etc.) produced political regimes with formal and liberal guarantees, but with a narrow popular participation. As Carlos de la Torre points out 'political parties and institutions controlled by traditional parties were perceived as instruments of local and foreign elites' (2016, p. 61).

Another point that underlines the non-democratic character of liberalism is the high percentage of Latin American people who is dissatisfied with liberal democracy, $71 \%$ in 2018. And the low percentage of people's confidence in liberal institutions such as congress, judiciary, and political parties in the same period of time with just $21 \%, 24 \%$, and $13 \%$ respectively (Latinobarometro 2018). It means that Latin American citizens believe that democracy is not working and constitutional institutions do not represent their demands, expectations, and necessities. In other words, liberal democracy does not have people's legitimacy and it does not represent people's will and confidence.

Hence, if constitutional democracy does not represent people, is it still a democracy? Or could it be a liberal regime without democracy? To answer these questions, it is crucial to understand that democratic consolidation is different than liberal consolidation. One society could have an institutionalized state which protects civil and political liberties, but at the same time low quantity and quality of participation beyond elections and vice versa (Zakaria 1997, p. 26; Rhoden 2015, p. 565).

Moreover, non-democratic liberalism, as its form of neoliberalism, is also based on economic exclusion and social marginalization because although Latin America has experienced a sustained economic growth in the last decade, there are still high rates of poverty such as: $34 \%$ of extreme 
poverty, $12,8 \%$ of poverty, inequality 0,47 GINI coefficient, unemployment $9,8 \%$, and informal work, 44,6\%, in 2018 (CEPAL 2018). Consequently, neoliberalism (liberal democracy and market economy) has not generated a society with equal labour, economic and social opportunities in the region. Thus, Latin America is not the poorest region in the world, however, it is the most unequal one. 165 and 69 million living in poverty and extreme poverty respectively, 25 million in unemployment and 134 million in informal economy. Hence, this political regime has suffered legitimacy issues because their social and economic performance (Pérez Liñán and Mainwaring 2013 p. 15).

Besides, poverty and inequality are not seen as simple results of 'neutral' and 'independent' public policies that did not work by Latin American people. They are seeing as the failure of a political and economic project -neoliberalism- which was designed to benefit to the elites in cost of the vast majority of the society. As can be seen in 2018, the regional average of people who believed that governments governed in benefit of the majority of the society was just $17 \%$. Likewise, the percentage of people who thought that politicians governed in favour for the elites was $79 \%$ (Latinobarometro 2018). Thus, neoliberalism was conceived as a non-democratic political and economic project which was materialized by elites in favour of themselves, while the rest of the society was politically, economically, and socially excluded.

On the other hand, some scholars (Zakaria 1997; Rhoden 2015; and Smith and Ziegler 2008) argue that constitutional democracies are the ideal ones. As a result, Latin American societies must work in favour of this cause since 'liberalization process begins before democratization and continues after democratic consolidation, we may think democracy as a stepping stone to a better liberalism' (Rhoden 2015 p. 569). Consequently, in a region characterized for dictatorships, populism, caudillos, and authoritarianism the role of liberalism to control power and protect individual rights throughout liberal institutions is a valid point.

However, political and economic institutions without mass incorporation, high rates of poverty and inequality, and lack of citizenship's 
participation could produce a political phenomenon which is characterized by its personalism and polarization. Furthermore, this political phenomenon constructs 'the people' as a relevant political actor in order to implement antiinstitutional changes. In other words, that political phenomenon is populism which the academic and political mainstream have configured as an antidemocratic and irrational alternative that destroys liberal democracy. This argument is completely valid because populist leaders concentrate power, dearticulate intermediate institutions, and construct a national enemy to justify its authoritarianism. Hence, populisms threat liberal democracies. However, if these democracies are the unique and legitimate democratic regimes what are the causes that produce the emergence of populist leaders in liberal political systems which, in theory, are a precondition of a democratic regime?

The answer depends on multiple factors that are not the essence of this academic work. But one of them is the antidemocratic character of liberalism which has historically emphasised the pre-eminence of institutional procedures in detriment of political participation and socio-economic inclusion in the region. As a result, Latin American populism represents not just a threat to individual rights, but also a 'democratic' force in order to integrate marginalized people to the liberal institutions through grass-root movements. Therefore, this argument will be explained in the following part of this essay. It means that populism has been a causal mechanism between non-democratic liberalism and illiberal democracies in Latin America.

\section{Populism: The people as a political construction to democratize (liberal) democracy}

Populism has been a political constant in the modern political history of Latin America; thus, there are different theoretical perspectives regarding populism in the region. One of them understands populism as a consequence of a process of desynchronization between social changes and institutional capacity (Di Tella 1973, p. 40). Other authors consider that this political phenomenon is the result of a class alliance between national bourgeoisie and labours, and this alliance is led by a nationalist populist caudillo (Cardoso and Faleto 1978, p. 69; O' Donnel 2011, p. 75). Additionally, populism could be understood as a political strategy in order to obtain or maintain power 
which is based on building national identity and Manichean discourse -the people against oligarchy- without any ideological tie (Night 2001, p. 162; Panizza 2009, p. 14).

For the purpose of this essay populism will be understood as a 'discourse that articulates popular democratic demands to challenge the dominant status quo' (Laclau 1977, p. 172). In other words, the populist phenomenon defies the institutional bloc of power throughout a political alternative that is based on the construction of the people (ideal concept) and its enemy (oligarchy) (Laclau 2009, p. 69). Hence, populist leaders have appeared in the recent years to challenge the dominant ideology, neoliberalism, in the region because of its ineffective and undemocratic outcomes such as poverty and marginalization, partyarchy and elites' monopolization of power.

Consequently, populism politicized the necessities, demands and expectations of Latin American people in order to break the constitutional and democratic consensus (political liberalism). Legal procedures and institutional arrangements were directly delegitimized by the populist leaders in the name of people, social justice and true democracy. As Panizza and Miorelli explain "populism marks a "rupture" with the existing unjust order and the "reconstruction" of a truly democratic order. In this new political order, the plebs (the underdogs) defeat their oppressors and become the demos (the legitimate holders of sovereignty)' (2009, p. 40).

For instance, in the last decade populist leaders arrived to power in Ecuador, Rafael Correa, Venezuela, Hugo Chavez, and Bolivia, Evo Morales; all of them challenged, criticized and dismantled economic and political liberalism appealing to the people through plebiscitarian democracy. 'Chavez, Morales and Correa used ballots to displaced political elites. They appealed to revolutionary force of constituent's power and convened participatory assemblies task with writing new constitutions that aimed to reinvent political, social, economic institutions' (De La Torre 2016, p. 62). Thus, in the name of the people, liberalism was attacked and populism played the role of a "democratic force" that democratized the non-democratic character of liberal democracy. 
However, this fake democratization ended up in the deinstitutionalization of political systems, the party systems, rule of law, and checks and balances. Not to mention that populist leaders weakened the separation of power, civil and political rights, the independence of the judiciary system and the agencies of control. As Panizza and Miorelli observe 'the fact that populism and democracy share common normative ground does not mean that populism is necessarily democratic' $(2009$, p. 40). For instance, Correa, Chaves, Morales, Ortega and Kirchner implemented different strategies such as: new constitutions, judiciary reforms through referendums, constitution's amendments in favour of unlimited re-elections, clientelism and so on. These permanent actions threatened the liberal principles of democracy since the latter was replaced by the people's will incarnated in the leader.

In other words, the populist phenomenon is characterized by two dimensions. On the one hand, populism demonstrates its democratic force through the inclusiveness of the underdogs in economic, social, political and cultural terms. On the other hand, populist leaders divide the political spectrum between two irreconcilable actors: the people versus the bloc of power. The latter is delegitimized and constructed as a national enemy which must be eliminated by the people.

In that sense, the populist phenomenon produces intended and unintended consequences with respect to democracy. It is based on the political and socioeconomic inclusion of the marginalized citizens. Albeit, this inclusiveness is materialized in a plesbiscitarian and anti-institutional manner. Consequently, populism, as well as democracy, is not an absolute and pure concept; it has multidimensional effects related to liberal institutions, political participation, and socio-economic inclusion which are key element that configure democratic regimes.

\section{Why is democracy in Latin America not liberal?}

Populist leaders were an answer to non-democratic liberalism, whereas they weakened the process of political institutionalization in the region emphasizing elections over constitutional mechanisms. In other words, populism produced another democracy with an adjective in Latin 
America, this time an illiberal democracy. As Smith and Ziegler say 'illiberal democracy occurs when free and fair elections combine with systematic denial of constitutional rights' $(2008$, p. 31). It means that Latin American populists appealed and used electoral democracy --plebiscites and referendato obtain, increase, and maintain political power. And at the same time dismantled liberal democracy.

In different countries of the region, a plebiscitarian democracy was established by presidents such as Correa, Chavez, Morales, Kirchner, and Ortega. They were elected with broad popular support, and used systematic elections in order to accumulate power, broke the rule of law, and threatened civil liberties. Thus, liberal values and principles were reconceptualised and underestimated in favour of a direct democracy where people could 'participate' directly in the decision making process through their votes instead of institutional procedures. As a result, populist leaders developed a democracy which was conceived as people's democracy, and the people was constructed as a collective political actor instead of individual citizens (Panizza and Miorelli 2009, p. 40).

This illiberal democracy was characterized by having formal procedures to elect representatives, but not institutional mechanisms to control political power. The concentration of the power was a fundamental step to consolidate a personalist form of government. For instance, Correa said publicly that he was the head of the whole state powers. In this vein, democracy was not liberal under populist regimes since pluralism, adversaries, minority's groups, and opposition were seen as caudillo's enemies. It meant that these actors were constructed as enemies of democracy, the country, and the people (Zakaria 1997, p.4; Panizza and Miorelli 2009, p.42; De la Torre 2016, p. 72). Hence, a liberal and constitutional democracy that respect and guarantee individual rights and balance of power could not emerge if one part of the society is seen as an enemy that must be destroyed.

Moreover, another characteristic that defines illiberal democracies in the region was the pre-eminence of the caudillo/leader/strongman over institutions which is 'the government by a single -usually charismatic- leader, driven by personal ambitions and with little interest in building institutions 
besides his own perpetuation in power' (Close and Deonadan 2004, p. 4). Consequently, strong and popular presidents imposed their will as the people's will through systematic elections and configured constitutions, laws, procedures and institutions based on their political interests. In this form, the institutionalized process of designing policies and polity was substituted by the personal and unilateral process of decision making.

These Latin American caudillos concentrated the institutional and impersonal power in their hands by replacing horizontal accountability and check and balances by vertical accountability (De la Torre 2016, p. 16). Furthermore, throughout elections the populist leaders appealed to the people in order to intervene and control judiciary systems, general attorney, and any institutional entity that could limit their absolute power. Therefore, the only power that has popular and sovereign legitimacy was the executive power, not for its institutional and legal basis, but because the caudillo 'incarnated' the people. Additionally, horizontal accountability was kidnapped and opposition was prosecuted. Thus, the liberal democracy characterized by its institutional arrangements to limit and account the power was systematically dismantled in favour of informal institutions, patronage, and clientelism. For instance, the Worldwide of Governance Indicators illustrate ${ }^{1}$ that in 2016 the regional average of voice and accountability was $60 \%$, but populist regime as Venezuela and Ecuador scored 20\% and 39\% respectively (World Bank 2016).

Besides, in regulatory quality Venezuela and Ecuador scored 5\% and $53 \%$, however, the regional average was $57 \%$ in 2016 . In the case of rule of law both countries were under the regional average with $2 \%$ for Venezuela and $25 \%$ for Ecuador. And in the field of control to corruption the average was $55 \%$ and Venezuela and Ecuador scored $10 \%$ and $27 \%$ respectively (World Bank 2016). These figures show that an illiberal democracy focuses only on the institutionalization of power in a single populist caudillo through electoral mechanisms. And it is inherently incapable to control corruption and guarantee rule of law because a liberal democracy is based on the institutionalization of power to be limited. As Zakaria observes 'constitutional

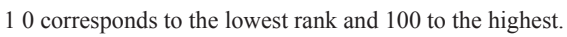


liberalism is about the limitation of power, democracy about its accumulation and use' (1997, p. 4).

On the other hand, some scholars argue that populism and illiberal democracy are really Latin American democracies because represent the politicization of bureaucratic and administrative issues which has been historically ruled by elites through institutions (Mouffe 2006, p. 17). This counter-argument justifies the existence of illiberal democracies taking into account the specific cultural, political, economic and social characteristics of the region. In other words, the construction of a liberal democracy is a utopia because the strong path dependence in Latin American countries. Consequently, the dispute of political power is a dilemma between illiberal quasi-authoritarian forces and populist leaders.

However, it is a fake dilemma because this counter-argument does not take into account that democracy, in any latitude or culture, is a sociopolitical construction which is constructed by collective actions. It means that democratic regimes, liberal or illiberal ones, are dynamic and changeable. Thus, the illiberal Latin American democracies are the result of a historic dispute between non-democratic liberalism and populism as a democratic illiberal force.

\section{Conclusion}

To conclude, non-democratic liberalism and illiberal democracies have been permanent patterns in the struggle for democracy in Latin America. The former has arguably generated economic and social marginalization, and the political participation was monopolized by elites through institutional arrangements, bureaucratic and administrative processes. The latter has possibly been the consequence of the non-democratic character of the constitutional democracy throughout the appearance of populist leaders that politicized and constructed the people as a collective political actor to pursue political change.

The Latin American illiberal democracy has diminished and threatened the basic liberal and constitutional guarantees such as: separation of powers, rule of law, independent judiciary system, free of association, press, opinion, 
religion, speech, and other individual rights. It because its plebiscitarian, antiinstitutional, and personalist character.

The argument of this essay does not delegitimize the necessity of liberal values to consolidate democratic systems in the region. It is unquestionable that solid institutions, rule of law, checks and balances, human rights, and separation of powers are determinant elements to guarantee development, peaceful coexistence, and democratic rule. In the same vein, the democratic character of populism in terms of multidimensional inclusion is not an apology to the authoritarian practices of populist leaders, which in effect are a threat to democracy. However, it is unavoidable that Latin American populism has played a relevant role in the understanding and construction of illiberal democratic systems.

Therefore, democracy in Latin America should be studied in the following years as a dynamic and integral concept that could not be divided between its institutional and inclusiveness characters. Finally, democracy without adjectives would possibly be an incomplete democracy. Thus, both institutions and inclusion have been, are, and must be the two-faces of Latin American democracies. 


\section{References}

Bustamante, G. (2012). "La razón populista versus la democracia representativa”. Revista Cultura Económica, 83, 20-35.

Cardoso, F. and Faleto, E. (1978). Dependencia y desarrollo en América Latina: Ensayo e interpretación sociológica. México D.F.: Siglo XXI Editores.

Comisión Económica para América Latina y el Caribe. (2018). Panorama social de América Latina 2016. Santiago: CEPAL.

Close, D. and Deonandan, K. (2004). Undoing democracy: the politics of electoral caudillismo. Lanham: Lexington Books.

Dahl, R. (2002). Poliarchy: participation and opposition. New Haven: Yale University Press.

De la Torre, C. (2016). "Left-wing populism: Inclusion and authoritarianism in Venezuela, Bolivia, and Ecuador". The Brown Journal of World Affairs, 23 (1), 61-76.

Di Tella, T. (1973). Populismo y reforma en América Latina. Santiago: Universitaria.

Fukuyama, F. (2004). The end of history and the last man. London: Hamish Hamilton.

Kruijt, D. (2001). "Low intensity democracies: Latin America in the Post-Dictatorial Era". Bulletin of the Latin American Research, 20 (4), 409430 .

Laclau, E. (1977). Politics and ideology in Marxist theory. London: Verso Books.

Laclau, E. (2009). La razón populista. Buenos Aires: Fondo de Cultura Económica.

Latinobarómetro (2018). Informe 2018. Santiago. Corporación 
Latinobarómetro.

Latinobarómetro (2015). Informe 1995-2015. Santiago. Corporación Latinobarómetro. Available at file://C:/Users/User/AppData/Local/Temp/ F00004377-DC_EVE_213_16-INFORME_LB_2015.pdf (Last visited 28 June 2020).

Night, A. (2001). "Democratic and Revolutionary traditions in Latin America". Bulletin of the Latin American Research, 20 (2), 147-186.

O’ Donnel, G. (2011). Modernización y autoritarismo. Buenos Aires. Prometeo.

Panizza, F. (2009). El populismo como espejo de la democracia. Buenos Aires: Fondo de Cultura Económica.

Panizza, F. and Miorelli, R. (2009). "Populism and Democracy in Latin America". Carnegie Council for Ethics in International Affairs. 39-46.

Perez-Liñan, A. and Mainwaring, S. (2013). "Regime legacies and levels of democracies: Evidence from Latin America". Comparative Politics, 45 (4), 379-395.

Rhoden, T. (2015). "The Liberal in Liberal Democracy". Democratization, 22 (3), 560-578.

Schumpeter, J. (1994). Capitalism, socialism, and democracy. London: Mansfield Centre.

Smith, P. and Ziegler, M. (2008). "Liberal and illiberal democracy in Latin America". Latin American Politics and Society, 50 (1), 31-57.

Wiarda, H. and Skelley, E. (2005). The dilemmas of democracy in Latin America: crises and opportunity. Lanham: Rowman \&Littlefield.

World Bank (2016). "Worldwide of Governance Indicators". Available at: http://info.worldbank.org/governance/wgi/index.aspx\#reports (Last visited 4 November 2019). 
¿IS DEMOCRACY IN LATIN AMERICA NOT LIBERAL AND IS LIBERALISM NOT DEMOCRATIC?

Zakaria, F. (1997). "The Rise of illiberal democracy". Foreign Affairs, 76 (6), 22-43. 